\title{
PENGARUH FUNGSI, UKURAN, DAN BENTUK JENDELA KEMASAN SERTA MODEL LIPATAN KEMASAN TERHADAP PERILAKU PEMBELIAN
}

\author{
Hardman Budiardjo ${ }^{1}$, Darwin Yuwono Riyanto ${ }^{2}$, Ixsora Gupita Cinantya ${ }^{3}$ \\ ${ }^{1,2,3}$ Program Studi Desain Komunikasi Visual, Fakultas Teknologi dan Informasi, \\ Institut Bisnis dan Informatika Stikom Surabaya \\ hardman@stikom.edu ${ }^{1}$, darwin@stikom.edu², ixsora@stikom.edu ${ }^{3}$
}

\begin{abstract}
Abstrak
Penelitian ini dilakukan untuk memperoleh temuan tentang pentingnya fungsi, ukuran, dan bentuk jendela kemasan, serta model lipatan kemasan dalam mempengaruhi perilaku pembelian. Obyek penelitian yang digunakan adalah kemasan J.Pops baby dan kemasan Holland Bakery. Pemilihan obyek penelitian ini karena representatif terhadap desain kemasan yang merupakan inti dalam keilmuan desain produk kemasan. Penelitian ini menggunakan pendekatan kuantitatif dengan teknik pengumpulan data melalui survey. Sedangkan teknik analisisnya menggunakan teknik analisis data Regresi Linear. Responden yang menjadi rujukan, berdomisili di Sidoarjo dan Surabaya dengan jumlah 106 konsumen. Hasil penelitian ini membuktikan bahwa fungsi jendela kemasan memiliki pengaruh secara positif dan signifikan terhadap perilaku pembelian. Sedangkan ukuran jendela kemasan, bentuk jendela kemasan, dan model lipatan kemasan tidak memiliki pengaruh terhadap perilaku pembelian. Temuan ini memberikan masukan kepada desainer yang bergerak di bidang kreatif kemasan untuk lebih memfokuskan pada fungsi jendela kemasan dari pada bentuk dan ukuran jendela kemasan, serta bentuk lipatan kemasan.
\end{abstract}

Kata Kunci: Jendela kemasan, Model lipatan, Perilaku pembelian

\begin{abstract}
This research was conducted to identify the importance of the function, size, and shape of the picture window and Packaging Folding Model that influencing buying behavior. Object of this research are J.Pops packaging and baby Holland Bakery packaging. This research uses a quantitative approach to data collection through surveys and data analysis using linear regression techniques. This research was conducted by 106 consumers domiciled in Sidoarjo and Surabaya. This research proves that only the window function packaging that has a positive and significant influence to the buying behavior. While the size of the packaging window, window shapes packaging and packaging folds models do not have an influence to the purchasing behavior. It advise designer who engaged in the field of creative packaging to focus more on function rather than shape and size of the windows packaging packaging folded models.
\end{abstract}

Keywords: Window Packaging, Folding Model, Buying behavior 


\section{PENDAHULUAN}

Penelitian ini memfokuskan pada pengaruh fungsi, ukuran dan bentuk jendela kemasan dan model lipatan kemasan terhadap perilaku pembelian. Penelitian ini ingin mendapatkan gambaran tentang fungsi, ukuran, dan bentuk jendela kemasan serta model lipatan terhadap perilaku pembelian. Penelitian yang pernah dilakukan berhubungan dengan perilaku pembelian produk beras yang dimediasi oleh kepercayaan merek [1]. Penelitian yang dilakukan di Sidoarjo, membuktikan pentingnya fungsi, ukuran, dan bentuk jendela kemasan serta model lipatan terhadap perilaku pembelian. Sedangkan penelitian yang berhubungan dengan pengaruh desain kemasan pada impulsive buying, yang dilakukan oleh Priscilla Christy dan J, Ellyawaty, menunjukkan bahwa desain kemasan memiliki pengaruh yang positif dan signifikan pada impulsive buying [2]. Desain kemasan yang dimaksudkan oleh Priscilla menekankan pada faktor estetika kemasan. Penelitian ini tidak menyinggung desain bentuk kemasan yang berhubungan dengan fungsi, ukuran, dan bentuk jendela kemasan, serta model locking kemasan, dan hanya menekankan pada visual art. Pada titik inilah penelitian akan dilakukan dengan menekankan pada kotak jendela kemasan dan model locking kemasan yang dihubungkan dengan perilaku pembelian.

Merek dengan kualitas yang tinggi dan menempati posisi dalam benak konsumen, menjadi tujuan setiap perusahaan dalam penawarannya. Dengan demikian merek akan memiliki keunggulan secara substansial, sehingga mampu bertahan dalam iklim persaingan pasar yang semakin ketat. Hal ini bermuara pada peningkatan ketertarikan dalam mengkaji dan mengukur persepsi kualitas dari konsumen dan pengaruhnya pada perilaku mereka [3]. Menurut Parasuraman et al, persepsi kualitas dalam pikiran konsumen dan pengaruhnya pada perilaku konsumen dewasa ini semakin banyak dikaji [3].

Hasil rangkuman kajian yang dilakukan oleh Zehir et al., menunjukkan bahwa dampak dari perilaku pembelian dapat ditentukan melalui prediktor terhadap persepsi kualitas dari konsumen yang terdiri atas kualitas tampilan dan kualitas layanan [4].

Untuk membangun hubungan yang kuat antara perusahaan dan konsumen dibutuhkan strategi pemasaran yang kuat. Hooley et al juga menyebutkan bahwa salah satu cara yang efektif untuk menciptakan kepercayaan merek adalah dengan meningkatkan persepsi kualitas dalam benak konsumen [5].

Kualitas produk salah satunya tercermin dari desain kemasan yang membungkus sebuah produk [6]. Termasuk didalamnya bagaimana kemasan dapat memperlihatkan isi produk secara langsung. Dalam hal ini desain kemasan dapat didasarkan melalui faktor komunikasi, faktor estetika dan faktor identitas. Faktor komunikasi dilihat sebagai media komunikasi yang menggambarkan produk, citra merek, dan bagian dari promosi agar mudah dilihat, dipahami, dan diingat. Penggambaran produk dapat dilakukan secara visual art, atau dengan memperlihatkan produk sebenarnya melalui kotak jendela kemasan, seperti yang dilakukan oleh beberapa kemasan kue Holland Bakery, dan J.PoPs baby donuts. 

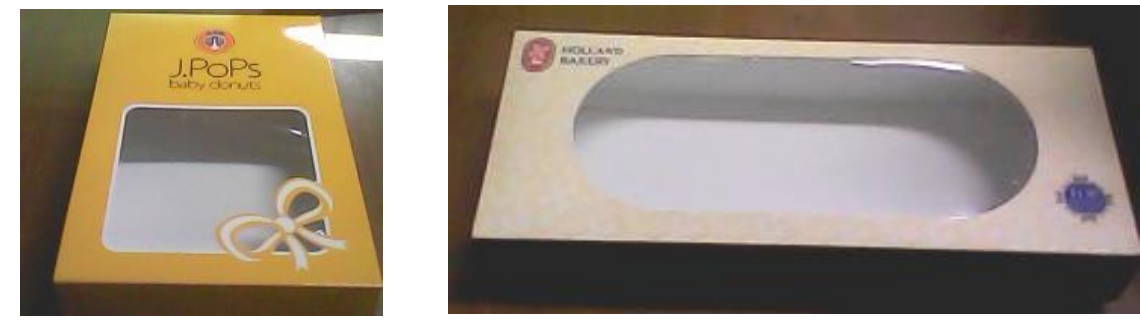

Gambar 5. Contoh Kotak Jendela Kemasan J.PoPs baby (kiri) dan Contoh Kotak Jendela Kemasan Holland Bakery (kanan)

[Sumber: Hardman, Darwin, \& Ixsora, 2016]

Idealnya, semakin baik desain kemasan yang membungkus produk maka diasumsikan bahwa persepsi kualitas produk juga semakin baik. Pada akhirnya membentuk sebuah keyakinan tertentu terhadap produk tersebut karena adanya persepsi kualitas. Keyakinan tersebut merupakan gambaran dari kepercayaan pelanggan terhadap sebuah produk yang kemudian biasa disebut sebagai kepercayaan merek. Dengan adanya persepsi kualitas produk yang baik dan tingginya kepercayaan terhadap produk, maka kondisi-kondisi tersebut dapat mempengaruhi perilaku pembelian.

Banyak penelitian yang sebenarnya sudah mengkaji pengaruh desain kemasan terhadap perilaku pembelian, namun sangat sulit menemukan penelitian yang menitikberatkan pada topik pembahasan pengaruh kotak jendela kemasan dan model lipatan kemasan sebagai implementasi dari kualitas produk terhadap perilaku pembelian. Hal inilah yang kemudian menjadi research gap atau kesenjangan penelitian yang selanjutnya dapat dimasuki. Oleh karena itu, penelitian ini mengkaji pengaruh kotak jendela kemasan dan model lipatan kemasan terhadap perilaku pembelian.

Penelitian ini dilakukan dengan tujuan untuk menguji pengaruh fungsi, ukuran, dan bentuk jendela kemasan serta model lipatan kemasan terhadap perilaku pembelian. Penelitian ini diharapkan dapat membangun model teoritik tentang peranan desain kemasan yang dalam hal ini adalah jendela kemasan dan model lipatan kemasan dalam membentuk terjadinya perilaku pembelian.

\section{METODE DAN HIPOTESIS PENELITIAN}

\subsection{Rancangan Penelitian dan Kerangka Konseptual}

Pada bagian ini dijelaskan ruang lingkup penyusunan proses analisis sebuah pengembangan model mengenai kotak fungsi, ukuran, bentuk jendela kemasan, model lipatan kemasan dan perilaku pembelian. Dasar dan landasan teori dalam penelitian ini tersusun dari kajian pustaka yang ada pada bagian sebelumnya sehingga dapat tercipta sebuah kerangka pemikiran teoritis. Penelitian ini sifat ekplorasi ilmu pengetahuan maka penelitian ini untuk mengkonfirmasi teori atas perkembangan permasalahan yang ada dalam persaingan pasar. 
Atas dasar hubungan tersebut maka dapat dibangun model konseptual sebagai berikut:

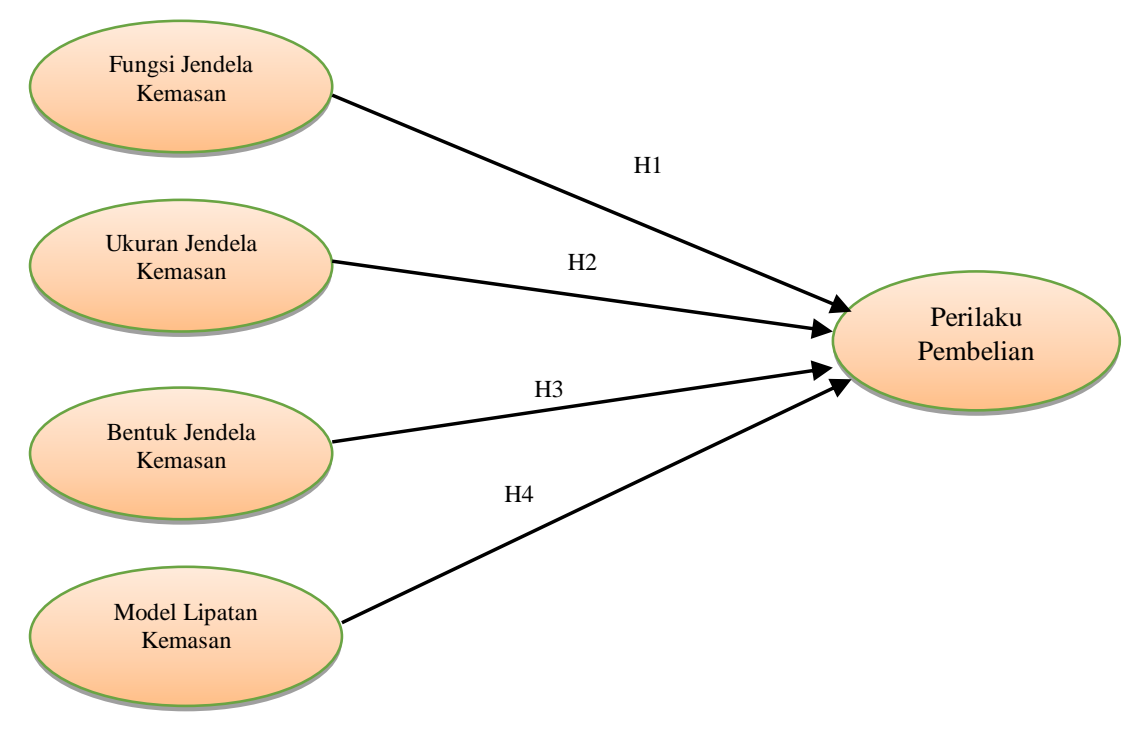

Gambar 6. Model Konseptual

[Sumber: Hardman, Darwin, \& Ixsora, 2016]

\subsection{Hipotesis Penelitian}

\subsubsection{Struktur Desain Kemasan}

Kemasan dengan struktur desain secara umumnya berada di pasar ritel seperti supermarket, grosir atau department store, dimana konsumen dari berbagai latar belakang nilai dan budaya berkumpul, maka struktur desain kemasan harus memiliki kemampuan untuk menarik perhatian konsumen dalam waktu yang cepat. Hal tersebut dapat dicapai dengan menerapkan elemen visual dan desain yang tidak hanya dapat menarik perhatian dari target konsumen, namun juga dapat menjadi pembeda sebuah merek dari produk lain yang sejenis. Selain elemen visual sebagai pembeda dalam hal ini adalah jendela kemasan model lipatan kemasan. Struktur desain jendela kemasan dan model lipatan kemasan yang baik dapat memancing konsumen memandang produk sebagai refleksi dari dirinya sendiri. Dari penjelasan tersebut maka dapat disusun hipotesis sebagai berikut:

H1 Fungsi jendela kemasan memiliki pengaruh positif yang signifikan terhadap perilaku pembelian

H2 Ukuran jendela kemasan memiliki pengaruh positif yang signifikan terhadap perilaku pembelian

H3 Bentuk jendela kemasan memiliki pengaruh positif yang signifikan terhadap perilaku pembelian

H4 Model lipatan kemasan memiliki pengaruh positif yang signifikan terhadap perilaku pembelian 


\subsubsection{Perilaku Pembelian}

Penggunaan perilaku pembelian atau intensi pembelian semakin meluas, khususnya dalam mengukur perilaku konsumen. Dimana pengukuran ini berasumsi bahwa niat merupakan indikator yag baik dari perilaku konsumen. Dari hasil penelitian dan pemasaran ranah psikologi telah memberikan identifikasi tiga alasan utama, yaitu terjadinya penyimpangan secara sistematis dalam laporan tentang behaviour, terjadinya pergeseran maksud yang sebenarnya dari waktu ke waktu akibat perubahan variabel penjelas, dan adanya korelasi yang tidak sempurna antara niat dan tindakan.

Studi-studi yang ada tidak semuanya menunjukkan adanya perbedaan ini dan memberikan estimasi yang tidak begitu akurat dan perkiraan bias terhadap korelasi antara niat dan pembelian. Model-model agregat mungkin berguna dala hal peramalan penjualan agregat namun hanya dapat membantu pemasar menargetkan konsumen individu sampai level tertentu. Identifikasi profil konsumen yang paling memungkinkan sebaiknya dilakukan oleh pemasar sehingga program pemasaran dapat disesuaikan dengan profil konsumen yang telah ditetapkan.

\subsection{Populasi, Sampel, dan Teknik Pengambilan Sampel}

Penelitian ini dilakukan di Sidoarjo dengan konsumen yang berbelanja di toko-toko tradisional ataupun di pasar-pasar modern. Pemilihan ini dilakukan karena peneliti ingin mendapatkan gambaran mengenai perilaku konsumen tanpa membedakan gender, usia, kelas, pendidikan ataupun behavior. Dengan tanpa membedakan segmen, maka jumlah populasi menjadi tidak terhitung, sehingga jumlah sampel ditetapkan berdasarkan persyaratan pengujian menggunakan alat analisis regresi berganda yaitu minimal 100 responden. Sedangkan teknik pengambilan sampel dilakukan dengan teknik convenience sampling dimana ketika ditemui konsumen membeli kemasan dengan struktur kotak jendela kemasan dan model lipatan kemasan, segera disodori angket, dimana dalam tes dalam angket tersebut juga berisi tentang kemasan branded as marketed tanpa kotak jendela kemasan (kemasan Kampung Roti) dan bentuk manual locking (kemasan Kampung Roti), kemudian diikuti kemasan branded as marketed dengan menggunakan kotak jendela kemasan (kemasan J.Pops baby dan kemasan Holland Bakery) dan bentuk locking automatis (kemasan J.Pops baby dan kemasan Holland Bakery). Setelah responden diobservasi lebih lanjut mengenai pendapat mereka tentang kemasan tersebut. Hal ini dilakukan karena ada produk yang memiliki brand image yang sangat kuat, sehingga hasil tes angket bisa saja berbeda mengalami perbedaan.

\subsection{Teknik Analisis Data}

Adapun Data yang didapatkan dalam penelitian ini diolah dan dinalisa dengan teknik regresi linear. Analisis regresi linier merupakan metode statistik yang digunakan untuk menguji hubungan linear antara variabel bebas atau independen $(X)$ dengan variabel terikat atau dependen (Y) [7].

Analisis regresi linier berfungsi untuk menentukan arah hubungan antara variabel independen dengan variabel dependen. Hasilnya hubungan masing-masing variabel 
independen apakah positif atau negatif dan juga untuk memprediksi nilai dari variabel dependen apabila nilai variabel independen mengalami kenaikan atau penurunan. Data yang dipakai dalam regresi linier berganda biasanya berskala interval atau rasio. Persamaan regresi linear berganda sebagai berikut:

$Y^{\prime}=a+b X$

Keterangan:

$Y \quad=$ Variabel dependen (nilai yang diprediksikan)

$\mathrm{X}=$ Variabel independen

$\mathrm{a} \quad=$ Konstanta (nilai intercept)

$\mathrm{b}=$ Koefisien arah regresi (nilai peningkatan ataupun penurunan). [7]

\section{HASIL DAN PEMBAHASAN}

\subsection{Instrumen Penelitian}

\subsubsection{Skala dan Pengukuran Data}

Dalam penelitian menggunakan pendekatan penelitian kuantitatif. Untuk menjadikan data kualitatif menjadi data bersifat kuantitatif digunakan skala Likert 4 poin dari poin 1 sampai poin 4 , dengan keterangan sangat tidak setuju (poin 1) sampai sangat setuju (poin 4). Skala Likert merupakan upaya penskalaan respon melalui prosedur penempatan sejumlah alternatif respon dari setiap item pada sebuah kontinum data kuantitatif sehingga diperoleh skor dari setiap alternatif respon. Dalam penggunaan skala Likert terlebih dahulu dibuat beberapa pernyataan yang berhubungan dengan obyek penelitian, kemudian responden diminta untuk menggambarkan tingkat kesetujuan atau ketidaksetujuan responden terhadap masingmasing pernyataan. Skala Likert merupakan salah satu teknik pengukuran sikap yang paling umum digunakan dalam penelitian periklanan.

\subsubsection{Uji Validitas dan Reliabilitas Instrumen Penelitian}

Instrumen penelitian yang telah disusun harus dilakukan pengujian terhadap validitas dan reliabilitasnya. Pengujian validitas dan reabilitas merupakan persyaratan penting yang berlaku bagi sebuah instrumen penelitian untuk memperoleh data penelitian. Dalam penelitian kualitatif, kriteria utama dalam pengumpulan data adalah, valid, reliable dan objektif [8]. Penyusunan sebuah angket harus benar-benar mampu mewakili tujuan dari penelitian yang dilaksanakan dan secara konsisten dapat digunakan bila angket tersebut dijawab dalam waktu yang berbeda. Alat pengujian instrumen penelitian menggunakan alat uji validitas dan reliabilitas. Pengujian ini digunakan untuk mengukur kualitas dari instrumen penelitian yang disusun.

Ketepatan instrumen (alat ukur) mampu melakukan kelayakan dapat diuji melalui pengujian validitas atau kesahihan. Dalam pengujian validitas suatu instrumen, alat ukur yang dapat digunakan berupa angka hasil korelasi antara skor pernyataan (yang berupa item atau butir-butir pertanyaan maupun skor dari faktor atau variabel) dengan total seluruh pertanyaan. Setelah dilakukan pengujian validitas instrumen, maka angket tersebut harus diuji reliabilitasnya. Reabilitas instrumen berkaitan dengan 
tingkat keyakinan (kepercayaan) terhadap instrumen atau sebuah tes. Suatu instrumen dengan tingkat kepercayaan yang tinggi, bila instrumen ini dapat memberikan hasil yang tetap (ajeg/stabil).

Uji coba (try out) angket dilakukan pada bulan September 2016 dengan sampel yang dilibatkan berjumlah 30 orang di Sidoarjo dengan tanpa memandang gender ataupun umur. Uji validitas menggunakan metode Pearson Cerrelation dimana suatu instrumen dapat dikatakan valid bila nilai Sig. (2-tailed) $<0,05$ dan nilai hitung Pearson Correlation lebih tinggi dari $R_{\text {tabel. }}$ Dari hasil pengujian seluruh variabel penelitian memiliki nilai Pearson Correlation lebih tinggi dari pada $R_{\text {tabel }}$ dan nilai Sig. (2-tailed) $<0,05$. Dengan demikian instrument penelitian sudah tepat dan valid atau sahih.

Uji reliabilitas dalam penelitian dilakukan dengan bantuan program SPSS yang mana instrumen dikatakan reliabel bila nilai hitung Alpha $>$ dari $R_{\text {tabel. Jumlah populasi }}$ penyebaran angket sebanyak 106 populasi. Dalam hal ini $R_{\text {tabel }}$ untuk $n=106$ adalah 0,1891 . Berdasarkan perhitungan melalui program SPSS seluruh variabel $(X 1, X 2, X 3$ dan $\mathrm{X4)}$ ) dilakukan pengujian dan diperoleh nilai hitung Alpha antara 0,5-0,8. Nilai hitung Alpha lebih besar dibandingkan dengan $R_{\text {tabel }}(0,1891)$. Dengan demikian instrumen penelitian dapat dipercaya sebagai alat ukur penelitian

\subsubsection{Uji Asumsi Instrumen Penelitian}

Pengujian asumsi bertujuan memberikan kepastian persamaan regresi yang diperoleh memiliki ketepatan estimasi, tidak adanya bias dan konsisten. Uji asumsi yang digunakan meliputi: uji normalitas, uji multikolinieritas, uji autokorelasi, Uji homoskedastisitas, dan uji linieritas [7].

Normal P-P Plot of Regression

Dependent Variable: $Y$

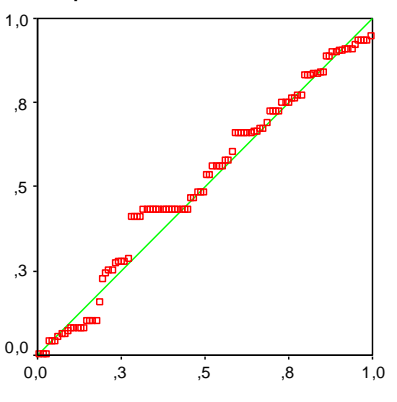

Observed Cum Prob

Gambar 7. Uji Normalitas

[Sumber: Husein Umar] [7]

Untuk menentukan apakah sebuah model regresi, variabel independen, variabel dependen, atau keduanya mempunyai distribusi normal atau tidak diperlukan Uji Normalitas. Model regresi yang baik bila memiliki distribusi data normal atau mendekati normal. Dari hasil pengujian dengan menggunakan program SPSS asumsi normalitas instrument penelitian terpenuhi, karena grafik P-P plot menunjukkan kecenderungan $45^{\circ}$ (lihat Gambar 3). Artinya data tersebar di antara garis grafik. Dengan demikian model tersebut memiliki distribusi normal. 
Uji multikolinieritas berguna untuk melakukan pengujian ada tidaknya korelasi antar variabel independen pada model regresi. Model regresi yang baik seharusnya tidak terjadi korelasi antar variabel independen. Setelah dilakukan pengujian multikol, model regresi tidak menunjukkan adanya multikol, karena VIF masih berkisar pada nilai 1. Ini berarti model regresi dapat digunakan dalam penelitian ini (lihat tabel 1).

Tabel 1. Hasil Uji Multikolinieritas

[Sumber: Husein Umar] [7]

Coefficients

\begin{tabular}{|c|c|c|c|c|c|c|c|c|c|c|c|}
\hline \multirow{2}{*}{\multicolumn{2}{|c|}{ Model }} & \multicolumn{2}{|c|}{$\begin{array}{l}\text { Unstandardized } \\
\text { Coefficients }\end{array}$} & \multirow{2}{*}{$\begin{array}{c}\text { Standardized } \\
\text { Coefficients } \\
\text { Beta } \\
\end{array}$} & \multirow[b]{2}{*}{$t$} & \multirow[b]{2}{*}{ Sig. } & \multicolumn{3}{|c|}{ Correlations } & \multicolumn{2}{|c|}{ Collinearity Statistics } \\
\hline & & B & Std. Error & & & & Zero-order & Partial & Part & Tolerance & VIF \\
\hline 1 & (Constant) & 1,247 & ,211 & & 5,903 &, 000 & & & & & \\
\hline & $\mathrm{X} 1$ & ,660 & 079 & ,794 & 8,344 & ,000 & ,713 & ,639 &, 573 &, 520 & 1,922 \\
\hline & X2 &,- 104 & ,073 &,- 129 & $-1,426$ & , 157 & ,393 &,- 141 &,- 098 &, 574 & 1,742 \\
\hline & X3 & 4,819E-02 & ,042 & ,083 & 1,149 & ,253 & , 191 & , 114 & ,079 & ,893 & 1,120 \\
\hline & $\mathrm{X} 4$ & $-1,85 \mathrm{E}-02$ &, 051 &,- 028 &,- 363 & ,718 & ,273 &,- 036 &,- 025 & ,784 & 1,276 \\
\hline
\end{tabular}

a. Dependent Variable: $Y$

Uji homoskedastisitas digunakan untuk menguji ada tidaknya ketidaksamaan varians dari residual dari satu pengamatan ke pengamatan lainnya dalam model regresi. Disebut homoskedastisitas, jika varians dari nilai residual dari satu pengamatan ke pengamatan yang lain tetap. Jika terjadi perbedaan dari satu pengamatan ke pengamatan yang lain, maka disebut heteroskedastisitas. Model regresi yang baik, bila tidak terjadi heteroskedastisitas atau model yang baik adalah yang homoskedastisitas. Grafik scatterplot hasil pengujian memperlihatkan titik-titik tersebar dengan baik di atas maupun di bawah angka nol sumbu Y (lihat gambar 4). Jadi dapat disimpulkan bahwa model regresi merupakan model homoskedastisitas atau varians dari nilai residual dari satu pengamatan ke pengamatan yang lain tetap.

Scatterplot

Dependent Variable: $Y$

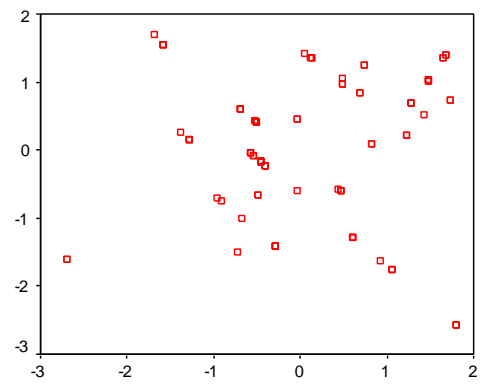

Regression Standardized Predicted Value

Gambar 8. Hasil Uji Homoskedastisitas

[Sumber: Husein Umar] [7]

Autokorelasi digunakan untuk menguji korelasi kesalahan pengganggu pada periode $\mathrm{t}$ dengan kesalahan pengganggu pada periode sebelumnya. Jika ditemukan kesalahan, maka kondisi ini dinamakan problem autokorelasi. Dari pengujian diperoleh $d u$ dari tabel Durbin Watson dengan alpha $5 \%$ dan $k$ (jumlah variabel bebas) $=4 \rightarrow 1,76$. Autokorelasi tidak terjadi, jika $\mathrm{du}<\mathrm{d}<4$-du $\rightarrow 1,76<1,910<2,24$ berarti tidak terjadi autokorelasi (lihat Tabel 2). 
Tabel 2. Hasil Uji Autokorelasi

[Sumber: Husein Umar] [7]

Model Summary

\begin{tabular}{|c|c|c|c|c|c|c|c|c|c|c|}
\hline \multirow[b]{2}{*}{ Model } & \multirow[b]{2}{*}{$\mathrm{R}$} & \multirow[b]{2}{*}{ R Square } & \multirow[b]{2}{*}{$\begin{array}{l}\text { Adjusted } \\
\text { R Square }\end{array}$} & \multirow[b]{2}{*}{$\begin{array}{l}\text { Std. Error of } \\
\text { the Estimate }\end{array}$} & \multicolumn{5}{|c|}{ Change Statistics } & \multirow[b]{2}{*}{$\begin{array}{c}\text { Durbin-W } \\
\text { atson }\end{array}$} \\
\hline & & & & & $\begin{array}{l}\text { R Square } \\
\text { Change }\end{array}$ & F Change & df1 & $\mathrm{df} 2$ & Sig. F Change & \\
\hline 1 & $724^{a}$ &, 524 &, 505 & $\star \star \star \star * \star * \star * \star \star * *$ & 524 & 27,789 & 4 & 101 &, 000 & 1,910 \\
\hline
\end{tabular}

a. Predictors: (Constant), X4, X2, X3, X1

b. Dependent Variable: $Y$

Tujuan penggunaan uji linieritas untuk mengetahui apakah dua variabel memiliki hubungan yang linear atau tidak secara signifikan. Syarat linier jika deviation from linierity $>0,05$. Dari uji linieritas, hubungan dua variabel antara $Y$ dan semua variabel $X$ memiliki linieritas, karena nilai sig deviation from linierity dibawah 0,05.

\subsection{Gambaran Umum Responden}

Tabel 3. Karakteristik Demografis Sampel Penelitian $(n=106)$

[Sumber: Hardman, Darwin, \& Ixsora, 2016]

\begin{tabular}{|c|c|c|c|}
\hline Karakteristik & & $\mathbf{N}$ & $\%$ \\
\hline \multirow{4}{*}{ Suka Makanan Ringan atau Kue } & Sangat Tidak Suka & 0 & $0 \%$ \\
\hline & Tidak Suka & 15 & $14,2 \%$ \\
\hline & Suka & 89 & $84,0 \%$ \\
\hline & Sangat Suka & 2 & $1,9 \%$ \\
\hline \multirow{4}{*}{ Pengetahuan tentang Jendela Kemasan } & Sangat Tidak Tahu & 0 & $0 \%$ \\
\hline & Tidak Tahu & 7 & $6,6 \%$ \\
\hline & Tahu & 98 & $92,5 \%$ \\
\hline & Sangat Tahu & 1 & $1,9 \%$ \\
\hline \multirow{4}{*}{ Pengetahuan tentang Lipatan Kemasan } & Sangat Tidak Tahu & 0 & $0 \%$ \\
\hline & Tidak Tahu & 2 & $1,9 \%$ \\
\hline & Tahu & 103 & $97,2 \%$ \\
\hline & Sangat Tahu & 1 & $0,9 \%$ \\
\hline \multirow{5}{*}{ Pendidikan } & Tidak Sekolah & 6 & $5,7 \%$ \\
\hline & SD & 0 & $0,0 \%$ \\
\hline & SMP & 10 & $9,4 \%$ \\
\hline & SMA & 61 & $57,5 \%$ \\
\hline & Perguruan Tinggi & 29 & $27,4 \%$ \\
\hline \multirow{4}{*}{ Pengeluaran per Bulan } & $<$ Rp. 1 juta & 45 & $42,5 \%$ \\
\hline & Rp. 1 juta - Rp. 2 juta & 17 & $16 \%$ \\
\hline & Rp. 2 juta - Rp. 3 juta & 8 & $7,5 \%$ \\
\hline & $>$ Rp. 3 juta & 34 & $32,1 \%$ \\
\hline \multirow{4}{*}{ Rumah } & Rumah Sendiri & 53 & $50 \%$ \\
\hline & Dengan Saudara & 2 & $1,9 \%$ \\
\hline & Dengan Orang Tua & 48 & $45,3 \%$ \\
\hline & Lain-lain & 3 & $2,8 \%$ \\
\hline
\end{tabular}

Angket penelitian ini disebarkan dengan cara mendatangi langsung subyek penelitian. Responden dipilih berdasarkan pertimbangan bahwa pembeli utama pernah membeli produk makanan ringan khususnya J.Pops baby, Holland Bakery dan Stupid Baker, 
dengan kemasan yang memiliki jendela kemasan (picture window) dan bentuk lipatan kemasan. Tidak ada pemilihan responden secara khusus dalam penyebaran angket. Lokasi penyebaran angket ini dilakukan di beberapa area di Sidoarjo dan Surabaya dengan tujuan agar temuan penelitian yang dihasilkan lebih representatif dalam menjelaskan model yang disusun dalam penelitian ini. Hal ini dapat dilihat dalam tabel 3 mengenai karakteristik demografis sampel penelitian bahwa tidak ada batasan gender responden yang menjadi subyek penelitian.

Dari seluruh responden terlihat adanya kecenderungan menyukai makanan ringan atau kue $84 \%$, dan $15,4 \%$ tidak menyukai makanan ringan, serta $1,9 \%$ sangat suka makanan ringan dari pabrikan. Penelitian ini tidak menemukan responden yang sangat tidak menyukai makanan ringan. Sedangkan pengetahuan tentang Jendela Kemasan didominasi oleh responden yang mengenal Jendela Kemasan sebesar 92,5\% dan tidak mengenal sebesar 6,6\%. Responden yang mengetahui tentang Lipatan Kemasan sebesar $97,2 \%$, sisanya antara tidak tahu sebesar $1,9 \%$ dan sangat tahu sebesar $0,9 \%$. Dalam hal pengeluaran belanja selama satu bulan didominasi oleh responden dengan anggaran belanja di bawah Rp. 1 juta, sedangkan anggaran belanja di atas Rp. 3 juta sebanyak 32,1\%. Adapun dalam aspek tempat tinggal, penelitian ini mendapati responden terbanyak di Sidoarjo sebesar $72,5 \%$. Dari seluruh responden mereka yang tinggal bersama orang tua sebanyak $45,3 \%$ sedangkan responden yang tinggal di rumah sendiri sebanyak $50 \%$.

\subsection{Penilaian Ukuran}

Penelitian ini menggunakan teknik analisis regresi linier untuk mengetahui hubungan antara variabel jendela kemasan, lipatan kemasan dan perilaku pembelian. Dalam tabel 4 dapat dilihat hasil pengujian model yang menunjukkan nilai sig dari tabel Annova < (0.05). Hal ini dapat dikatakan bahwa model yang digunakan telah memenuhi unsur signifikan.

Tabel 4. Pengujian Model berdasarkan tabel Anova

[Sumber: Hardman, Darwin, \& Ixsora, 2016]

\section{ANOVA}

\begin{tabular}{|c|c|c|c|c|c|c|}
\hline Model & & $\begin{array}{l}\text { Sum of } \\
\text { Squares }\end{array}$ & df & Mean Square & $\mathrm{F}$ & Sig. \\
\hline \multirow[t]{3}{*}{1} & Regression & 8,276 & 4 & 2,069 & 27,789 &, $000^{a}$ \\
\hline & Residual & 7,520 & 101 & ,074 & & \\
\hline & Total & 15,796 & 105 & & & \\
\hline
\end{tabular}

a. Predictors: (Constant), X4, X2, X3, X1

b. Dependent Variable: $Y$

Hasil pengujian model konseptual secara bersama-sama yang diperlihatkan pada tabel 4 menunjukkan bahwa model konseptual signifikan, karena nilai sig < alpha $(0,05)$. Oleh karenanya, pengujian model konseptual dilanjutkan dengan uji satu persatu untuk memperoleh gambaran signifikansi setiap variabel, seperti yang ditunjukkan pada tabel 4. 
Tabel 5. Pengujian Variabel

[Sumber: Hardman, Darwin, \& Ixsora, 2016]

\begin{tabular}{|c|c|c|c|c|c|c|c|c|c|c|c|}
\hline \multicolumn{12}{|c|}{ Coefficients } \\
\hline \multirow[b]{2}{*}{ Mod } & & \multicolumn{2}{|c|}{$\begin{array}{l}\text { Unstandardized } \\
\text { Coefficients }\end{array}$} & \multirow{2}{*}{$\begin{array}{c}\begin{array}{c}\text { Standardized } \\
\text { Coefficients }\end{array} \\
\text { Beta } \\
\end{array}$} & \multirow[b]{2}{*}{ t } & \multirow[b]{2}{*}{ Sig. } & \multicolumn{3}{|c|}{ Correlations } & \multicolumn{2}{|c|}{ Collinearity Statistics } \\
\hline & & B & Std. Error & & & & Zero-order & Partial & Part & Tolerance & VIF \\
\hline 1 & (Constant) & 1,247 & 211 & & 5,903 &, 000 & & & & & \\
\hline & $\mathrm{X} 1$ & 660 & ,079 & 794 & 8,344 & ,000 & ,713 & ,639 & ,573 & ,520 & 1,922 \\
\hline & $\mathrm{X} 2$ &,- 104 & ,073 &,- 129 & $-1,426$ & 157 & ,393 &,- 141 &,- 098 & ,574 & 1,742 \\
\hline & X3 & 4,819E-02 & ,042 & ,083 & 1,149 & 253 & 191 & 114 & ,079 & 893 & 1,120 \\
\hline & $\mathrm{X} 4$ & $-1,85 \mathrm{E}-02$ & 051 &,- 028 &,- 363 & ,718 & ,273 &,- 036 &,- 025 & ,784 & 1,276 \\
\hline
\end{tabular}

a. Dependent Variable: $Y$

Berdasarkan hasil pengujian satu persatu variabel dengan menggunakan Pearson Correlation, nilai sig yang diperoleh dari tabel ANOVA < alpha $(0,05)$. Hasil nilai hitung uji Annova variabel X1 < alpha $(0,05)$. Artinya variabel X1 memiliki pengaruhi terhadap perilaku pembelian secara positif. Hal ini berarti bahwa semakin besar X1 akan semakin berpengaruh terhadap perilaku pembelian. Sedangkan nilai variabel X2 (skor $0,157)$, variabel X3 (skor 0,253), dan variabel X4 (skor 0,718) memiliki nilai skor > alpha $(0,05)$. Artinya variabel $X 2, X 3$ dan $X 4$ tidak memiliki pengaruh terhadap perilaku pembelian.

Dengan demikian variabel $\mathrm{X} 1$ yang mengukur fungsi jendela kemasan memiliki pengaruh terhadap perilaku pembelian. Jendela kemasan memiliki manfaat dalam mempengaruhi perilaku pembelian oleh konsumen, karena dengan melihat isi produk dalam kemasan secara langsung, memiliki keyakinan terhadap kualitas dibandingkan dengan melihat produk secara visual.

Sedangkan variabel $\mathrm{X} 2$ yang mengukur ukuran jendela kemasan, variabel $\mathrm{X} 2$ ( bentuk jendela kemasan), dan variabel X3 (model lipatan kemasan) menunjukkan hasil tidak signifikan atau lebih besar dari alpha $(0,05)$. Dengan kata lain variabel ukuran jendela kemasan, bentuk jendela kemasan, dan model lipatan kemasan tidak memiliki pengaruh terhadap perilaku pembelian. Besar kecilnya ukuran dan bentuk jendela kemasan tidak tidak mewakili manfaat atau fungsi meyakinkan isi produk dalam kemasan terhadap konsumen. Ukuran dan bentuk jendela kemasan lebih memiliki kecenderungan terhadap nilai estetika kemasan dari pada manfaat kemasan. Demikian pula dengan model lipatan kemasan. Konsumen tidak melihat apakah kemasan dilipat dengan model autolock, semi autolock, atau manual. Bagi konsumen yang diutamakan dapat melihat isi produk secara langsung. 
Tabel 6. Uji Korelasi

[Sumber: Hardman, Darwin, \& Ixsora, 2016]

Correlations

\begin{tabular}{|ll|r|r|r|r|r|}
\hline & & \multicolumn{1}{|c|}{$\mathrm{Y}$} & \multicolumn{1}{|c|}{$\mathrm{X} 1$} & \multicolumn{1}{|c|}{$\mathrm{X} 2$} & \multicolumn{1}{c|}{ X3 } & \multicolumn{1}{c|}{ X4 } \\
\hline Pearson Correlation & $\mathrm{Y}$ & 1,000 &, 713 &, 393 &, 191 &, 273 \\
& $\mathrm{X} 1$ &, 713 & 1,000 &, 652 &, 169 &, 385 \\
& $\mathrm{X} 2$ &, 393 &, 652 & 1,000 &, 134 &, 243 \\
& $\mathrm{X} 3$ &, 191 &, 169 &, 134 & 1,000 &, 322 \\
& $\mathrm{X} 4$ &, 273 &, 385 &, 243 &, 322 & 1,000 \\
\hline Sig. (1-tailed) & $\mathrm{Y}$ &, &, 000 &, 000 &, 025 &, 002 \\
& $\mathrm{X} 1$ &, 000 &, 000 &, 041 &, 000 \\
& $\mathrm{X} 2$ &, 000 &, 000 &, 000 &, 085 &, 006 \\
& $\mathrm{X} 3$ &, 025 &, 041 &, 085 &, &, 000 \\
& $\mathrm{X} 4$ &, 002 &, 000 &, 006 &, 000 &, \\
\hline $\mathrm{N}$ & $\mathrm{Y}$ & 106 & 106 & 106 & 106 & 106 \\
& $\mathrm{X} 1$ & 106 & 106 & 106 & 106 & 106 \\
& $\mathrm{X} 2$ & 106 & 106 & 106 & 106 & 106 \\
& $\mathrm{X} 3$ & 106 & 106 & 106 & 106 & 106 \\
& $\mathrm{X} 4$ & 106 & 106 & 106 & 106 & 106 \\
\hline
\end{tabular}

Sedangkan besarnya hubungan antara variabel $\mathrm{X}$ dan $\mathrm{Y}$ diuji dengan metode Pearson Correlation. Uji korelasi (lihat tabel 6) antara variabel X1 (fungsi jendela kemasan) dengan perilaku pembelian diperoleh nilai sebesar 0,713 atau $71,3 \%$. Sedangkan variabel X2 (ukuran jendela kemasan) dengan perilaku pembelian menghasilkan nilai 0,393 atau 39,3\%, variabel X3 (bentuk jendela kemasan) memperoleh nilai 0,191 atau $19,1 \%$, dan variabel X4 (model lipatan kemasan) memperoleh nilai 0,273 atu $27,3 \%$. Dari uji korelasi di atas, maka variabel $\mathrm{X} 1$ memiliki pengaruh positif dan signifikan terhadap variabel $Y$ dengan $r$ sebesar 0.71 atau 71\%, artinya setiap peningkatan variabel fungsi $\left(\mathrm{X}_{1}\right)$, maka akan meningkatkan variabel perilaku pembelian $(\mathrm{Y})$.

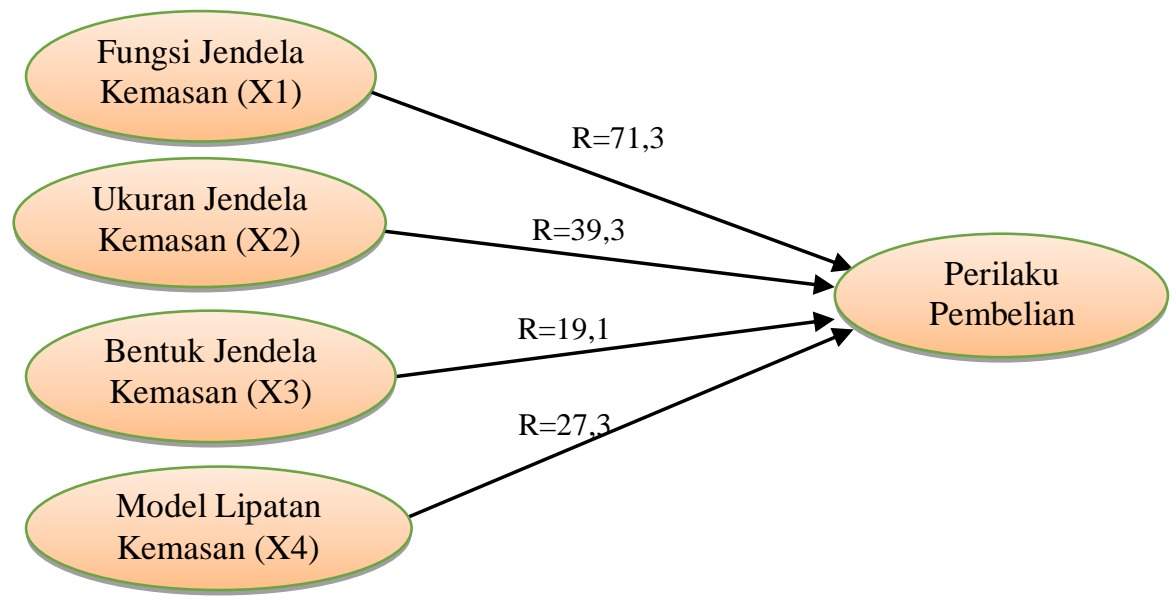

Gambar 5. Hasil Uji korelasi Model Konseptual

[Sumber: Hardman, Darwin, \& Ixsora, 2016]

Tampak dalam gambar 5 bahwa hipotesis dalam penelitian ini yang menyebutkan bahwa jendela kemasan sebagai fungsi memiliki pengaruh positif yang signifikan 
terhadap perilaku pembelian terbukti benar. Sedangkan variabel ukuran jendela kemasan, bentuk jendela kemasan, dan model lipatan kemasan tidak memiliki pengaruh secara positif. Hal ini bisa dijelaskan bahwa desain kemasan yang memanfaatkan bentuk dan ukuran jendela kemasan hanya memberikan nilai tambah pada estetik kemasan. Namun tidak memberikan nilai pada fungsi dari jendela kemasan, yang bertujuan memberikan informasi yang sebenarnya terhadap isi kemasan. Demikian pula dengan model lipatan kemasan yang tidak berhubungan langsung dengan isi kemasan. Sehingga model lipatan kemasan tidak memiliki pengaruh secara positif terhadap perilaku pembelian.

\section{KESIMPULAN}

\subsection{Kesimpulan}

Penelitian ini dilakukan dengan tujuan untuk menguji pengaruh jendela kemasan (fungsi, ukuran, dan bentuk) dan model lipatan kemasan terhadap perilaku pembelian. Obyek yang diobservasi dalam penelitian ini adalah perilaku pembelian terhadap produk makanan ringan dengan ohjek penelitian adalah kemasan J.Pops Baby, dan Holland Bakery. Ketiga produk ini memiliki kemasan yang jendela dan berbagai bentuk model lipatan kemasan. Responden dalam penelitian ini adalah bersifat umum yang berdomisili di daerah Sidoarjo, dan Surabaya.

Penelitian ini berhasil membuktikan pentingnya fungsi jendela kemasan dalam mempengaruhi perilaku pembelian secara positif. Sedangkan dari ukuran dan bentuk picture windows, tidak berpengaruh terhadap perilaku pembelian. Demikian pula dengan bentuk lipatan kemasan yang tidak berpengaruh terhadap perilaku pembelian. Sedangkan dari hasil deskripsi profil responden dapat dilihat bahwa responden memiliki kecenderungan menyukai makanan ringan atau kue. Artinya bahwa responden atau konsumen hanya memerlukan jendela kemasan yang dapat berfungsi memperlihatkan isi kemasan dalam mengambil keputusan pembelian dengan cepat, yang dalam studi kasus ini menggunakan kemasan J.Pops baby dan kemasan Holland Bakery, dibandingkan dengan kemasan yang tidak memperlihatkan isi kemasan.

\subsection{Saran}

Berdasarkan pada hasil pembahasan dan kesimpulan, maka terdapat beberapa saran untuk penelitian selanjutnya seperti ditambahkannya variabel-variabel penelitian lain berupa desain kemasan atau menitikberatkan pada area penelitian di kota lain atau bahkan di provinsi yang lain serta memfokuskan observasi pada subyek penelitian yang berbeda misalnya pada kepala rumah tangga atau kepada remaja sehingga hasil penelitian yang didapatkan dapat menggambarkan model penelitian secara lebih presisi sehingga model penelitian yang diteliti dapat digeneralisasikan dengan baik. 


\section{DAFTAR PUSTAKA}

[1] Budiardjo, Hardman. 2016. The Impact of Packaging Design to Purchase Behavior through Brand Trust. International Journal of Business and Management Invention, Vol. 5-Issue 1-Version-1.

[2] Priscilla Christy \& J, Ellyawaty. 2015. Pengaruh Desain Kemasan (Packaging) Pada Impulsive Buying. Program Studi Manajemen, Fakultas Ekonomi, Universitas Atma Jaya Yogyakarta Jalan Babarsari No. 43 - 44, Yogyakarta

[3] Parasuraman, A., Zeithaml, V.A. \& Berry, L.L. 1988. SERVQUAL: A multi-Item scale for measuring consumer perceptions of service quality. Joumal of Retailing, Vol. 64, pp. 13-40.

[4] Zehir, Cemal; Sahin, Azize; Kitapci, Hakan and Ozsahin, Mehtap. 2011. The Effects Of Brand Communication And Service Quality In Building Brand Loyalty Through Brand Trust. The Empirical Research On Global Brands, The 7th International Strategic Management Conference. Paris-France.

[5] Hooley, G.I., Greenley, G.E., Cadogan, J.W. and Fahy, J. 2005. The Performance Impact Of Marketing Resources. Journal of Business Research, Vol. 58 No. 1, pp. 18-27.

[6] Julianti, Sri. 2014. The Art Of Packaging: Mengenal Metode, Teknik, dan Strategi Pengemasan Produk untuk Branding dengan Hasil Maksimal. Penerbit: PT. Gramedia Pustaka Utama. Jakarta.

[7] Husein Umar. 2007.Metode Penelitian untuk Skripsi dan Tesis Bisnis. Edisi Kedua. Jakarta: PT Raja Grafindo Persada.

[8] Sugiono. 2011. Metode Penelitian Kombinasi. Bandung: Penerbit Alfabeta. 